Original Research

\title{
Differences in The Measurement of The Right And Left Form of Blood Pressure in Hypertension Patients
}

\author{
Anang Nurmoko', Ana Fadilah', Eny Pujiati²
}

1 STIKES Cendekia Utama Kudus, Indonesia

2 AKPER Krida Husada Kudus, Indonesia

\section{Article Info}

\section{Article History:}

Submit July 15 th, 2020

Accepted Sept 17th, 2020

Published Sept 30th 2020

\section{Keywords:}

Blood Pressure;

Hypertension

\section{INTRODUCTION}

Hypertension is defined as an increase in blood pressure that remains above an agreed normal limit, ie diastolic $90 \mathrm{mmHg}$ or systolic $140 \mathrm{mmHg}$. Hypertension is one of the number one causes of death, globally. Hypertension is the most common cause of cardiovascular events and is a major

\begin{abstract}
Hypertension is one of the number one causes of death, globally. Hypertension is the most common cause of cardiovascular events and is a major problem in both developed and developing countries. Cardiovascular is also the number one cause of death in the world every year. Respondents in this study were patients with a diagnosis of hypertension in hospitalized patients at Mardi Rahayu Kudus Hospital, totalling 41 people. the characteristics of hypertension patient respondents seen from the age of the most patients are in the late adult age category (36-45 years), namely 31 people (75.6\%), while for early adulthood (26-45 years). 35 years) as many as 10 people (24.4\%). The characteristics of hypertension patient respondents seen from the sex of the most patients were male, namely 25 people $(61.0 \%)$, while the female gender was 16 people $(39.0 \%)$. Results The highest systolic blood pressure was $170 \mathrm{mmHg}$ and the lowest was 145 $\mathrm{mmHg}$. The average systolic blood pressure was $152.90 \mathrm{mmHg}$. In hypertensive patients on the left arm, the highest systolic blood pressure was $170 \mathrm{mmHg}$ and the lowest was $145 \mathrm{mmHg}$. The average systolic blood pressure was $152.90 \mathrm{mmHg}$. Based on the dependent t-test, the t value is 12.491 with a p-value of 0.000 . It can be seen that the p-value is $0.000<$ ? (0.05), this indicates that there is a significant difference in the results of blood pressure measurements between the right arm and the left arm in hypertensive patients in the inpatient room of Mardi Rahayu Kudus Hospital. The difference in blood pressure variations obtained in this study is still considered normal because the difference in MAP between the right and left arms is $6.11 \mathrm{mmHg}$ (normal $10-20 \mathrm{mmHg}$ ).
\end{abstract}

problem in both developed and developing countries. Cardiovascular is also the number one cause of death in the world every year. ${ }^{1}$

The results of measuring blood pressure are influenced by several factors, namely the activities carried out before the measurement, the pressure or stress to be

Corresponding author:

Eny Pujiati

eny.pujiati@yahoo.co.id

South East Asia Nursing Research, Vol 2 No 3, September 2020

ISSN:2685-032X

DOI: https://doi.org/10.26714/seanr.2.3.2020.105-110 
experienced, the measurement time, and the position when the measurement is standing or sitting ${ }^{2}$. Lifestyle changes such as smoking, obesity, physical inactivity and psychosocial stress can cause various diseases, one of which can attack the cardiovascular system, especially hypertension. WHO, data shows that around 1.13 billion people in the world suffer from hypertension. This means that 1 in 3 people in the world are diagnosed with hypertension, only $36.8 \%$ of them are taking medication.

The number of hypertension sufferers in the world continues to increase every year, it is estimated that by 2025 there will be 1.5 billion people affected by hypertension. It is also estimated that every year 9.4 million people die from hypertension and complications. ${ }^{3}$ In Indonesia, based on Kemenkes RI, 2019 data, the prevalence of hypertension in Indonesia is $25.8 \%$, the highest prevalence is in Bangka Belitung $(30 \%)$ and the lowest is in Papua (16.8\%). Meanwhile, data from the 2016 National Health Indicator Survey shows an increase in the prevalence of hypertension among people aged 18 years and over by $32.4 \% .^{4}$ In addition, according to BPJS Health data, the cost of hypertension services has increased every year, namely Rp. 2.8 trillion in 2014, Rp. 3.8 trillion in 2015, and Rp. 4.2 trillion in 2016. Based on the Basic Health Research (Riskesdas) the prevalence of hypertension in Central Java increased from 7.6 per million in 2007 to 9.5 peril in 2013.5 This means that out of a thousand inhabitants it is estimated that there are more than 9 people suffering from this disease. Meanwhile, based on data from the Central Java Provincial Health Office 2017, of the eleven types of non-communicable diseases, hypertension is the most common disease suffered by the people of Central Java with a proportion of $55 \%$, while the data available at Mardi Rahayu Kudus Hospital between January to October 2018 were obtained. hypertension cases were 1340 cases. $^{6}$
Hypertension which continues to increase should be controlled. The way is to measure blood pressure correctly. According to several existing theories that the way blood pressure measurements should be done on both arms (right and left). Variations in blood pressure can be found in different arteries. Normal variation is common in both arms, but should not exceed $5-10$ mmHg. A difference of more than $10 \mathrm{mmHg}$ is an indication of vascular disorders, and if the difference is greater than $20-30 \mathrm{mmHg}$ in both arms indicates a suspicion of organic disturbances in blood flow in areas with low blood pressure. ${ }^{2}$

In fact, where there is measurement of blood pressure on only one arm, especially at Mardi Rahayu Kudus Hospital. Likewise, when facing SNARS accreditation in 2018, blood pressure measurement tools are required to use a digital tensimeter related to mercury tensimeter which is not recommended again. ${ }^{7}$ From these phenomena, this study aims to determine the differences in measurements on the right and left arms of the results of blood pressure in hypertensive patients in the inpatient room of Mardi Rahayu Kudus Hospital.

\section{METHODS}

The design of this study is to use a comparative analytical research design with a cross sectional approach, where the research object is only observed once and measurements are made of the status of the character or object variable at the time of examination by approaching and collecting data at once. The measuring instrument uses a digital tensimeter. The test test used is the dependent $t$ test. The sample in this study was 41 respondents at the Mardi Rahayu Kudus hospital in April 2019 with a purporsive sampling technique. In this study, researchers took blood pressure measurements taken on the respondents' right and left arms, then analyzed the extent to which the measurement results differed in the respondent's two arms. 


\section{RESULTS}

Respondents in this study were patients with a diagnosis of hypertension in hospitalized patients at Mardi Rahayu Kudus Hospital, totaling 41 people. Based on table 1 above, it shows that the characteristics of hypertension patient respondents seen from the age of the most patients are in the late adult age category (36-45 years), namely 31 people $(75.6 \%)$, while for early adulthood (26-45 years). 35 years) as many as 10 people (24.4\%). It shows that the characteristics of hypertension patient respondents seen from the sex of the most patients were male, namely 25 people $(61.0 \%)$, while the female gender was 16 people (39.0\%).

Table 1

Frequency Distribution Based on Age and Gender of

\begin{tabular}{lcc}
\multicolumn{2}{c}{ Hypertension Patients in the Inpatient Room } \\
\hline \multicolumn{1}{c}{ Indicators } & $\mathrm{f}$ & $\%$ \\
\hline Age & & \\
$\quad$ Early Adult & 10 & 24,4 \\
$\quad$ Late Adult & 31 & 75,6 \\
\hline Sex & & \\
$\quad$ Man & 25 & 61,0 \\
$\quad$ Female & 16 & 39,0 \\
\hline
\end{tabular}

The result shows that the results of measuring the blood pressure of hypertensive patients on the right arm, the highest systolic blood pressure is 175 $\mathrm{mmHg}$ and the lowest is $150 \mathrm{mmHg}$. The mean systolic blood pressure was 159.68 $\mathrm{mmHg}$ with a standard deviation of 6.28 mmHg. Then for diastolic blood pressure has a highest value of $120 \mathrm{mmHg}$ and a low value of $95 \mathrm{mmHg}$. The average diastolic pressure was $105.56 \mathrm{mmHg}$ with a standard deviation of $5.78 \mathrm{mmHg}$. Furthermore, from the results of systolic and diastolic blood pressure in the right arm, the highest MAP value was $138.3 \mathrm{mmHg}$ and the lowest was $114.0 \mathrm{mmHg}$ with an average result of $122.94 \mathrm{mmHg}$ with a standard deviation of $5.44 \mathrm{mmHg}$.

Based on table 2, it shows that the results of measuring blood pressure in hypertensive patients on the left arm, the highest systolic blood pressure is $170 \mathrm{mmHg}$ and the lowest is $145 \mathrm{mmHg}$. The mean systolic blood pressure was $152.90 \mathrm{mmHg}$ with a standard deviation of $5.93 \mathrm{mmHg}$. Then for diastolic blood pressure, the highest blood pressure is $110 \mathrm{mmHg}$ and the lowest is $85 \mathrm{mmHg}$. Diastolic blood pressure averaged 98.80 $\mathrm{mmHg}$ with a standard deviation of 5.8 $\mathrm{mmHg}$. Furthermore, from the systolic and diastolic blood pressure results in the left arm, the highest MAP value was 130.0 $\mathrm{mmHg}$ and the lowest MAP value was 106.0 $\mathrm{mmHg}$, with an average result of 116.83 $\mathrm{mmHg}$ with a standard deviation of 5.59 $\mathrm{mmHg}$.

This bivariate analysis was used to determine differences in measurements on the right and left arms of the results of blood pressure in hypertensive patients in the inpatient room of Mardi Rahayu Kudus Hospital. To find out this difference, a difference test in the results of the MAP of the right and left arms was used in hypertensive patients using the dependent $t$ test.

Based on table 2, it shows that the average MAP result for the right arm is 122.94 mmHg, while on the left arm shows the MAP result is lower, which is $116.83 \mathrm{mmHg}$, with an average MAP difference of $6.11 \mathrm{mmHg}$. Furthermore, after the normality test was carried out, it was found that the two data were normally distributed, namely MAP kiri sig. 0.821 and MAP right sig. 0.346 ( $p>0.05$ ). Based on the results of the normality test, then continued with the dependent t test, the $t$ value is -12.491 with a p-value of 0.000 . It can be seen that the p-value is $0.000<$ ? (0.05), this indicates that there is a significant difference in the results of blood pressure measurements between the right arm and the left arm in hypertensive patients in the inpatient room of Mardi Rahayu Kudus Hospital. 
Table 2

Mean differences of blood pressure in the Right and Left Arm in Patients Hypertension in the Inpatient

\begin{tabular}{|c|c|c|c|}
\hline \multicolumn{4}{|c|}{ Room (n=82) } \\
\hline \multirow{2}{*}{ Indicators } & \multicolumn{2}{|c|}{ Group } & \multirow[t]{2}{*}{$\mathrm{p}$} \\
\hline & Right Arm & Left Arm & \\
\hline Systolic & $\begin{array}{l}159,68 \\
( \pm 6,28)\end{array}$ & $\begin{array}{l}152,90 \\
( \pm 5,93)\end{array}$ & \\
\hline Diastolic & $\begin{array}{l}104,56 \\
( \pm 5,78)\end{array}$ & $\begin{array}{r}98,80 \\
( \pm 5,88)\end{array}$ & 0.000 \\
\hline MAP & $\begin{array}{l}122,94 \\
( \pm 5,44)\end{array}$ & $\begin{array}{l}116,83 \\
( \pm 5,59)\end{array}$ & \\
\hline
\end{tabular}

\section{DISCUSSION}

Based on the research conducted, it shows that the results of blood pressure measurements of hypertensive patients on the right arm, the highest systolic blood pressure is $175 \mathrm{mmHg}$ and the lowest is 150 mmHg. The mean systolic blood pressure was $159.68 \mathrm{mmHg}$ with a standard deviation of $6.28 \mathrm{mmHg}$. Then for diastolic blood pressure has a highest value of 120 $\mathrm{mmHg}$ and a low value of $95 \mathrm{mmHg}$. The average diastolic pressure was 105.56 $\mathrm{mmHg}$ with a standard deviation of 5.78 mmHg. Furthermore, from the results of systolic and diastolic blood pressure in the right arm, the highest MAP value was 138.3 $\mathrm{mmHg}$ and the lowest was $114.0 \mathrm{mmHg}$ with an average result of $122.94 \mathrm{mmHg}$ with a standard deviation of $5.44 \mathrm{mmHg}$.

The results of this study were obtained after measuring the right arm of 41 respondents who suffered from hypertension by measuring the patient in a lying position on the bed. The highest systolic blood pressure value was $170 \mathrm{mmHg}$ and the lowest was $150 \mathrm{mmHg}$ and the highest diastolic pressure was $120 \mathrm{mmHg}$ and the lowest was $95 \mathrm{mmHg}$. This is in accordance with the theory which says that a person is said to have hypertension, which means that the average arterial pressure is higher than the limit considered normal. In a resting state when the mean arterial pressure is higher than $110 \mathrm{mmHg}$ (normal around $90 \mathrm{mmHg}$ ) then this is considered hypertension; this value occurs when the diastolic blood pressure is greater than $90 \mathrm{mmHg}$ and the systolic pressure is greater than approximately 135 to $140 \mathrm{mmHg}{ }^{8}$

Many factors play a role in the occurrence of hypertension, apart from cardiac output factors, peripheral vessel resistance, blood volume, viscosity and elasticity of the walls of blood vessels in a person's body which causes blood pressure not to be constant. Artiyaningrum, B., Azam, M 2016 identified several conditions that can affect blood pressure, including age, weight, emotions, activity, race, gender, and drugs. In the study, the most age group suffering from hypertension was late adulthood (aged 3645 years), namely 31 people $(75.6 \%)$ from a total of 41 respondents. This is in accordance with the theory that a person's age affects blood pressure in humans, the older a person, generally his blood pressure will increase. ${ }^{9}$

In children there is no significant difference in blood pressure between boys and girls. However, after puberty, men tend to have higher blood pressure. Conversely, after menopause women have higher blood pressure than men their age. This is in line with the results of the research obtained, that some of the respondents were male, namely 25 people $(61.0 \%)$, while the female gender was 16 people (39.0\%).

Based on the results of the study showed that the results of measuring blood pressure in hypertensive patients on the left arm, obtained the highest systolic blood pressure of $170 \mathrm{mmHg}$ and the lowest of $145 \mathrm{mmHg}$. The mean systolic blood pressure was $152.90 \mathrm{mmHg}$ with a standard deviation of $5.93 \mathrm{mmHg}$. Then for diastolic blood pressure, the highest blood pressure is $\mathbf{1 1 0}$ $\mathrm{mmHg}$ and the lowest is $85 \mathrm{mmHg}$. Diastolic blood pressure averaged $98.80 \mathrm{mmHg}$ with a standard deviation of $5.8 \mathrm{mmHg}$. Furthermore, from the systolic and diastolic blood pressure results in the left arm, the highest MAP value was $130.0 \mathrm{mmHg}$ and the lowest MAP value was $106.0 \mathrm{mmHg}$, with an average result of $116.83 \mathrm{mmHg}$ with a standard deviation of $5.59 \mathrm{mmHg}$. 
The results of this study were also obtained after measuring the left arm of 41 respondents who suffered from hypertension by measuring the patient in a lying position on the bed. The age group suffering from hypertension ranged from 36-45 years and there were more men. Hypertension or high blood pressure is an increase in systolic blood pressure of more than $140 \mathrm{mmHg}$ and diastolic blood pressure of more than $90 \mathrm{mmHg}$ on two measurements with an interval of five minutes in a state of rest / calm. ${ }^{5}$

Based on the results of research related to differences in measurements on the right and left arms on the results of blood pressure in hypertensive patients in the inpatient room of Mardi Rahayu Kudus Hospital, it was found that there was a significant difference in measurements between the right arm and the left arm. This is indicated by the MAP average result for the right arm of $122.94 \mathrm{mmHg}$, while the left arm shows the lower MAP result of 116.83 $\mathrm{mmHg}$, with an average MAP difference of $6.11 \mathrm{mmHg}$. After doing the test with the dependent $t$ test, the $t$ value is -12.491 with a p-value of 0.000 . It can be seen that the $p$ value is $0.000<\alpha(0.05)$, this indicates that there is a significant difference in the results of blood pressure measurements between the right arm and the left arm in hypertensive patients in the inpatient room of Mardi Rahayu Kudus Hospital. The difference in blood pressure variations obtained in this study is still considered normal because the difference in MAP between the right and left arms is 6.11 mmHg, this is supported by the theory that blood pressure variations can be found in different arteries. Normal variation is common in both arms, but should not exceed 5 - $10 \mathrm{mmHg}$. A difference of more than $10 \mathrm{mmHg}$ is an indication of a vascular disorder, and if the difference is greater than 20-30 mmHg in both arms, it indicates a suspicion of an organic disturbance of blood flow in areas with low blood pressure. $^{2}$
High blood pressure (hypertension) is an increase in blood pressure in the arteries. In general, hypertension is an asymptomatic condition, in which abnormally high pressure in the arteries leads to an increased risk of stroke, aneurysm, heart failure, heart attack and kidney damage. Meanwhile, according to iqbal and jamal, hypertension is a condition in which a person experiences an increase in blood pressure above normal which results in an increase in morbidity and mortality. ${ }^{10}$

Blood pressure in adults is classified into 6, namely normal blood pressure, high normal, stage 1 (mild hypertension), stage 2 (moderate hypertension), stage 3 (severe hypertension), and stage 4 (malignant hypertension). Normal blood pressure is blood pressure where the systolic pressure is below $130 \mathrm{mmHg}$ and the diastolic pressure is below $85 \mathrm{mmHg}$, while normal high blood pressure is blood pressure where the systolic pressure is $130-139$ $\mathrm{mmHg}$ and the diastolic pressure is $85-89$ mmHg. Stage I blood pressure (mild hypertension) is blood pressure where the systolic pressure is $140-159 \mathrm{mmHg}$ and the diastolic pressure is $90-99 \mathrm{mmHg}$. Stage 2 blood pressure (moderate hypertension) is blood pressure where the systolic pressure is $160-179 \mathrm{mmHg}$ and the diastolic pressure is $100-109 \mathrm{mmHg}$. Stage 3 blood pressure (severe hypertension) is blood pressure where the systolic pressure is 180-209 $\mathrm{mmHg}$ and the diastolic pressure is 110-119 $\mathrm{mmHg}$. Stage 4 blood pressure (malignant hypertension) is blood pressure where the systolic pressure is $210 \mathrm{mmHg}$ or more and the diastolic pressure is $120 \mathrm{mmHg}$ or more. ${ }^{10}$

The results of the above study are also in line with the previous study entitled "Analysis of differences in the results of blood pressure measurements between the right arm and the left arm in hypertensive patients at RSUD. DR.H. Abdul Moeloek, Lampung Province" by Arwani and Sunarno. The results of statistical analysis show that there is a significant difference 
between the results of blood pressure measurements taken on the right arm and the results of blood pressure measurements taken on the left arm in hypertensive patients at RSUD DR. H. Abdul Moeloek Lampung $(\mathrm{p}=0.012)$.

\section{CONCLUSION}

Based on the dependent $t$ test, the $t$ value is -12.491 with a p-value of 0.000 . It can be seen that the p-value is $0.000<0.05$, this indicates that there is a significant difference in the results of blood pressure measurements between the right arm and the left arm in hypertensive patients in the inpatient room of Mardi Rahayu Kudus Hospital. The difference in blood pressure variations obtained in this study is still considered normal because the difference in MAP between the right and left arms is $6.11 \mathrm{mmHg}$ (normal 10-20 $\mathrm{mmHg}$ ).

\section{ACKNOWLEDGMENTS}

The researcher would like to say thank you to all respondents who participated in this research.

\section{CONFLICTS OF INTEREST}

Neither of the authors has any conflicts of interest that would bias the findings presented here.

\section{REFERENCES}

1. Carey RM, Whelton PK, Aronow WS, et al. Prevention, detection, evaluation, and management of high blood pressure in adults: Synopsis of the 2017 American College of Cardiology/American Heart Association Hypertension Guideline. Ann Intern Med 2018; 168: 351-358.

2. Ratulangi USAM, Danes VR, Skripsi $\mathrm{K}$, et al. Analisa Hasil Pengukuran Tekanan Darah Antara Posisi Duduk Dan Posisi Berdiri Pada Mahasiswa Semester Vii (Tujuh) Ta. 2014/2015 Fakultas Kedokteran Universitas Sam Ratulangi. eBiomedik 2015; 3: 125-129.

3. Organization WH. World Health Statistics Overview 2019: monitoring health for the SDGs, sustainable development goals. Geneva, 2019.

4. Badan Penelitian dan Pengembangan Kesehatan. Riset Kesehatan Dasar (RISKESDAS) 2013. Lap Nas 2013 2013; 1-384.

5. Kementerian Kesehatan. Hasil Utama Riset Kesehata Dasar (RISKESDAS). 2018. Epub ahead of print 2018. DOI: 10.1088/17518113/44/8/085201.

6. Dinas Kesehatan Provinsi Jawa Tengah. Profil Kesehatan Provinsi Jateng Tahun 2019. 2019.

7. Komisi Akreditasi Rumah Sakit. Standar Nasional Akreditasi Rumah Sakit Edisi 1. 2017; 421.

8. Tanto C, Liwang F, Hanifati S PE. Kapita Selekta Kedokteran. 2017.

9. Muhadi. JNC 8: Evidence-based Guideline Penanganan Pasien Hipertensi Dewasa. Cermin Dunia Kedokt 2016; 43: 54-59.

10. Iqbal AM JS. Essential Hypertension. [Updated 2020 Jul 10]. Treasure Island (FL): StatPearls Publishing 2020; https://www.ncbi.nlm.nih.gov/books/NBK539 859/. 